\title{
Aspects of the hydrophobic effect sustainability obtained in plasma for cotton fabrics
}

DOI: $10.35530 / I T .070 .03 .1475$

\section{REZUMAT - ABSTRACT}

Aspecte ale sustenabilității efectului hidrofob obținut în plasmă pentru țesăturile din bumbac

Această lucrare prezintă mai multe aspecte privind evaluarea ciclului de viață (LCA) pentru țesăturile de bumbac $100 \%$ tratate cu diferite tipuri de compuși ai fluorului utilizând tehnologia cu plasmă RF și tehnologia de fulardare, pentru a obține efectul hidrofob. Pentru a evidenția efectele obținute prin tehnologia cu plasmă RF (radiofrecvența) s-a efectuat în paralel un studiu privind efectul hidrofob obținut utilizând o dispersie de compuși de fluor (NUVA TTC) pe fulard. Concluziile studiului au fost că, dacă se utilizează tratamentul cu plasmă pentru efectul hidrofob, atunci acest lucru ar influența negativ mediul prin încălzirea generată de gaze și consumul de energie, atunci când se utilizează metoda de fulardare și substanțele chimice deja stabilite, impactul ar consta în creșterea consumului de combustibili fosili, substanțe anorganice respiratorii și schimbări climatice. A fost analizat inventarul ciclului de viață (LCI) și evaluarea ciclului de viață (LCA) folosind software-ul SimaPro și Eco-indicator 99. Pentru obținerea LCl, au fost utilizate datele tehnice de intrare și ieșire din procesul de plasmă/fulard și software-ul SimaPro pentru a genera LCA pe baza acestor date. Datele de intrare despre materia primă, energie, substanțele chimice au fost colectate prin măsurători directe pe echipamente, manuale de utilizare ale dispozitivelor și specificații ale echipamentelor (cărți tehnice) și procese. Datele de ieșire (energia reziduală și substanțele chimice) au fost obținute utilizând statistici, baze de date de pe internet și software-ul SimaPro. Obiectivul inițiativei noastre științifice a fost studierea sustenabilității tehnologiei cu plasmă RF utilizate pentru hidrofobizare și s-a dovedit că tehnologia cu plasmă utilizată pentru efectul hidrofob este mai puțin ecologică decât tehnologia de fulardare pentru o unitate funcțională de $1 \mathrm{~kg}$ de material tratat.

Cuvinte-cheie: textil, plasma RF, hidrofobizare, LCA, LCI, mediu

\section{Aspects of the hydrophobic effect sustainability obtained in plasma for cotton fabrics}

This paper presents several aspects concerning the life cycle assessment (LCA) for $100 \%$ cotton fabric treated with different types of Fluor compounds using RF plasma technology and foulard technology, in order to obtain the hydrophobic effect. To highlight the effects obtained by RF (radio frequency) plasma technology was conducted in parallel a study about hydrophobic effect obtained using a dispersion of fluorine compound (NUVA TTC) on foulard. The conclusions of the study were that if we use the plasma treatment for hydrophobic effect then this would influence the environment negatively by warming generated by gases and power consumption, when using the foulard method and chemical substances already established, the impact would consist of increasing the consumption of fossil flues, respiratory inorganics, and climate change. We analyzed the life-cycle inventory (LCI) and life-cycle assessment (LCA) using SimaPro software and Eco-indicator 99. For obtaining the $\mathrm{LCl}$, we used to input and output technical data, from the plasma / foulard process, and the SimaPro software for generating the LCA based on these data. The input data about raw material, energy, chemical substances, have been collected by direct measurements on machinery, device logs and specifications of the equipment (technical books) and processes. The output data (waste energy and chemicals) were obtained using statistics, internet databases, and SimaPro software. The objective of our scientific initiative has been to study the sustainability of the RF plasma technology used for hydrophobization, and we obtained that plasma technology used for hydrophobic effect is less eco-friendly than foulard technology for a functional unit of $1 \mathrm{~kg}$ treated material.

Keywords: textile, RF plasma, hydrophobization, LCA, LCl, environment

\section{INTRODUCTION}

The environmental impact categories identified (carcinogenic, inorganic compounds upon the breath, climate change, radiation, ozone layer, eco-toxicity, land use, minerals, and fossil fuels) have been obtained by using the method ECO indicator 99. In order to obtain the life-cycle assessment (LCA) [1], it is necessary to analyze the life-cycle inventory ( $\mathrm{LCl}$ ) for hydrophobic textiles obtained by standard technology (foulard method) and by advanced technology
(RF plasma [2, 3]). Moreover, it is necessary to collect inputs and outputs for the duration of the life cycle of the (figure 1), for both treatments carried out using fluorine compounds such as NUVA TTC, sulfur hexafluoride, and Teflon. The inputs and outputs requested for ICV and LCA are:

1. Inputs:

- Raw materials;

- Energy used;

- The water used; 


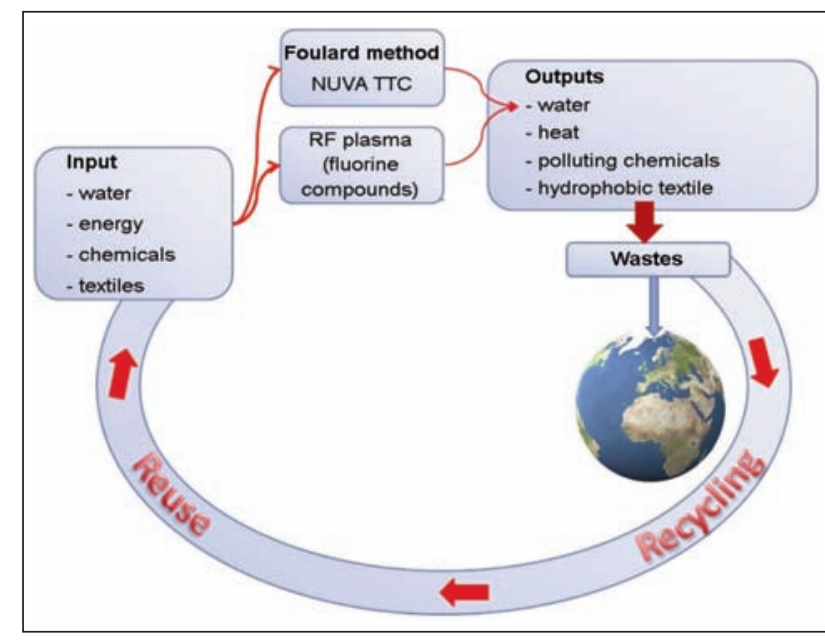

Fig. 1. Input/Output - foulard and plasma technologies

- The main ratio between the hydrophobic product and co-products;

- The rate of production.

2. Outputs:

- The waste discharged into the ambient environment.

For evaluating life-cycle as compared, within the framework of this phase, data were collected from both technological processes of RF plasma and foulard method, directly, indirectly by sources available on the internet (specific databases) and literature on the subject [4-7].

ECO-Indicator Method 99 provides quantification of the impact for environmental processes by categories of impact: carcinogenic substances results, harmful organic and inorganic substance through breathing, climatic changes caused by the substances with the greenhouse effect, radiation, changes that take place at the level of the ozone layer, ecotoxicity, acidification/Eutrophication, land use, minerals and consume fossil fuels for power generation.

For the assessment of environmental impact, by SimaPro7, have been used methods of normalization, weighting, single score and "damage assessment" (assessment of the extent of damage) [8, 9].

- The normalization method shows the extent to which a category of impact has a significant influence on the environment.

- The weighting method has as its objective reporting to the category of impact on the relative importance of it.

- The single score method involves the specification of the multiplication of substances, which contribute to the impact, with a factor of specification expressing the relative contribution of the substance.

- The method of assessing the degree of damage "damage assessment" aims the combination of some categories of impact in order to obtain a category of damage, also called the protection zone.

\section{EXPERIMENTAL PART}

The experimental part consisted of the development of the LCA comparative assessments studies for hydrophobic materials obtained. Data were collected from the industrial, technological process and secondary sources such as internet database and specialty scientific literature and were used to establishing the LCA [7-8]. The input data for LCI and LCA are presented in table 1 for the hydrophobization process using plasma equipment, respective for classical hydrophobization process using foulard equipment.

\begin{tabular}{|c|c|c|}
\hline \multicolumn{3}{|c|}{ INPUT DATA FOR HYDROPHOBIZATION USING PLASMA PROCESS USING PLASMA } \\
\hline Data about the industrial process & U.M. & Value \\
\hline \multicolumn{3}{|l|}{ 1. Data about fabric consumption } \\
\hline Fibrous composition & \multicolumn{2}{|l|}{$100 \%$ cotton } \\
\hline Width & $\mathrm{cm}$ & 150 \\
\hline \multirow{2}{*}{ Mass } & $\mathrm{g} / \mathrm{m}^{2}$ & 401 \\
\hline & $\mathrm{g} / \mathrm{ml}$ & 602 \\
\hline Mass (the fabric used in the industrial process) & $\mathrm{kg}$ & 100 \\
\hline \multicolumn{3}{|c|}{ 2. Data about plasma equipment (energy and chemicals consumptions) } \\
\hline Plasma equipment & W & 1215 \\
\hline \multicolumn{3}{|l|}{ 2.1 Data about chemicals substances consumption } \\
\hline Argon gas & $\mathrm{cm}^{3}$ & 800 \\
\hline Fluorine compounds & $\mathrm{kg} / 100 \mathrm{~kg}$ fabric & 21.14 \\
\hline 2.2 Process duration & $\min$ & 10 \\
\hline \multicolumn{3}{|l|}{ 3. Data about foulard equipment consumptions } \\
\hline 3.1 Water for treatment solution & L water/100 kg fabric & 74 \\
\hline 3.2 NUVA TTC & $\mathrm{kg} / 100 \mathrm{~kg}$ fabric & 5.6 \\
\hline 3.3 Methane gas & $\mathrm{m}^{3}$ & 90 \\
\hline 3.4 Electrical energy & $\mathrm{kW}$ & 95 \\
\hline 3.5 Process duration & $\min$ & 108 \\
\hline
\end{tabular}


SimaPro7 can evaluate the impact on the environment through the following approaches: normalization, characterization, weighting, damage assessment and Single Score [9-11].

The normalization is a procedure required to show the extent to which a category of impact has a significant contribution to the general problem of the environment, and is done using the division of the category indicator of impact by a value of "Normal" [12-14].

The weighting method has as its objective the quantitative aggregation of the results of using the weighting factors. This kind of approach has an impact on categories reported between these categories. Each category of impact is multiplied by weight [14-15].

The characterization method consists in the multiplication of all impact categories by a factor which reflects the relative contribution to the environmental impact, quantifying how much impact has the hydrophobic textile obtained by foulard and by RF plasma in each impact category.

The single score method is based on weighting method and is presented the impact on each input of the system.

The damage-assessment method uses different procedures to establish the relationship between the inputs and the potential damages. For example, the damage analysis in the model for human health impact links health effects to the number of Years Lived Disabled (YLD) and Years of Life Lost (YLL) [16].

The impact types obtained by SimaPro are presented in the following diagrams:

- LCA comparative assessment using method for the evaluation of damage (figure 2);

- LCA comparative assessment using the normalization method (figure 3);
- LCA comparative assessment using characterization method (figure 4);

- LCA comparative assessment using the weighting method (figure 5);

- LCA comparative assessment using Single Score method (figure 6).

In figure 2 is presented the damage assessment of the process that involves RF plasma, and fluorine compounds have a $100 \%$ impact on all categories. The classical treatment based on the foulard method and NUVA TTC has a lower impact, the higher values being for fossil fuels consumption (10\%), ecotoxicity $(6 \%)$, harmful organic chemicals by respiration $(6 \%)$, chemicals with carcinogenic effect $(4 \%)$, ocean acidification by $\mathrm{CO}_{2}$ emissions into atmosphere (4\%) and harmful inorganic chemicals by respiration (3\%).

In figure 3 is presented the normalization diagram and is visible that RF plasma treatments have a $100 \%$ impact on environment generating climate changes due to the emissions in the atmosphere. Also, the impact on electrical energy consumption generates an impact on fossil fuels consumption. From figure 3 can be observed a minor impact or even zero by respiratory organics, radiation, land use and ecotoxicity as a consequence of the plasma technology because low-pressure plasma technology does not generate organics vapors emissions, heat, and wastewater.

In figure 4 is presented the characterization diagram and is evident that for all categories the RF plasma technology has an impact of $100 \%$, while the impact of the classical technologies has values lower the $10 \%$, such as for fossil fuels consumption the impact is $9.5 \%$, for ecotoxicity and harmful organic chemicals by respiration the impact approximated to $6 \%$. In figure 6 is presented the Single Score diagram for comparative LCA RF plasma vs. foulard method, and

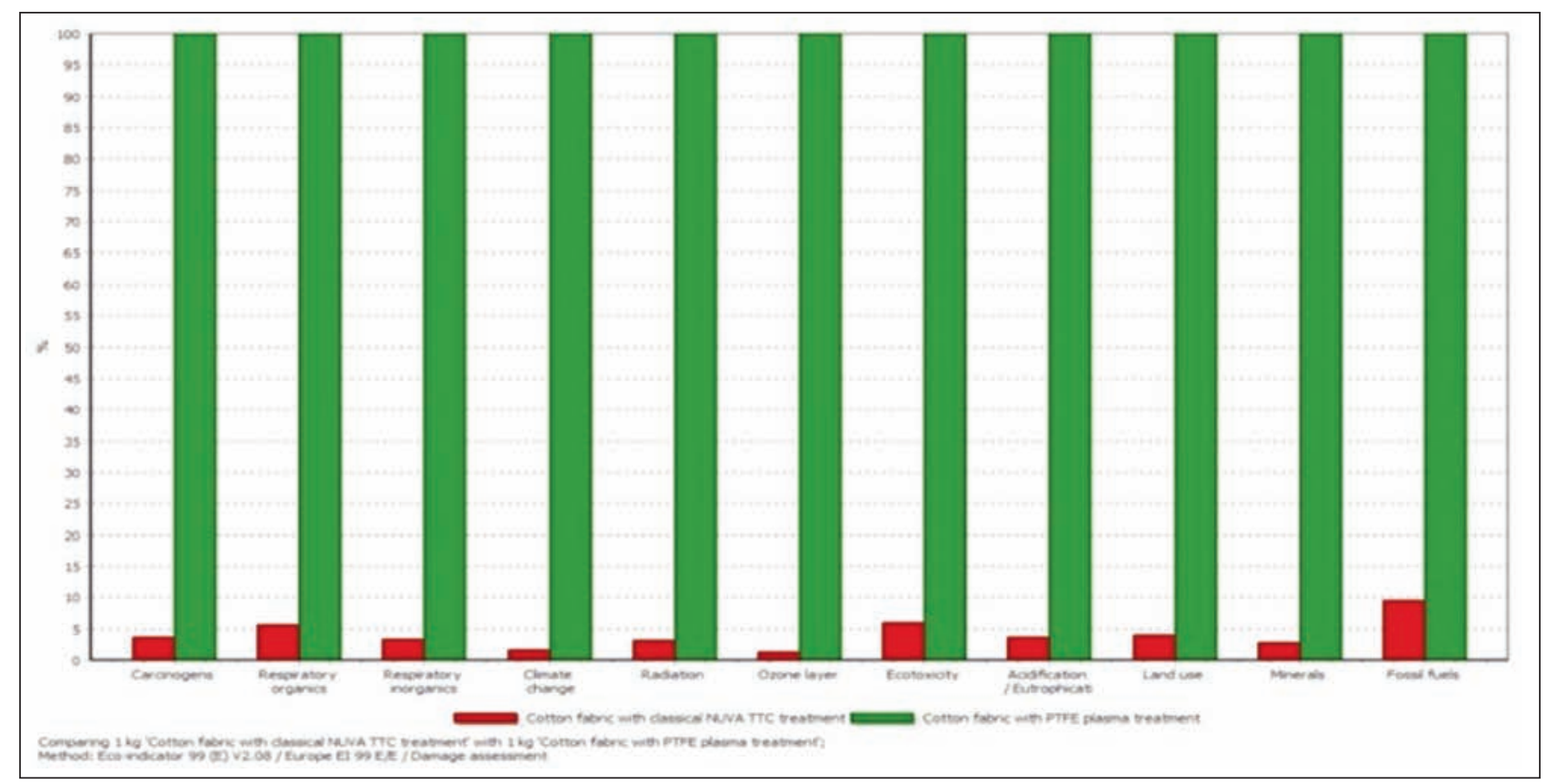

Fig. 2. The histogram of the comparative assessment of the impact of the life cycle for hydrophobic cotton fabric obtained by foulard with NUVA TTC and by RF plasma (Teflon), using the method for the evaluation of damage 


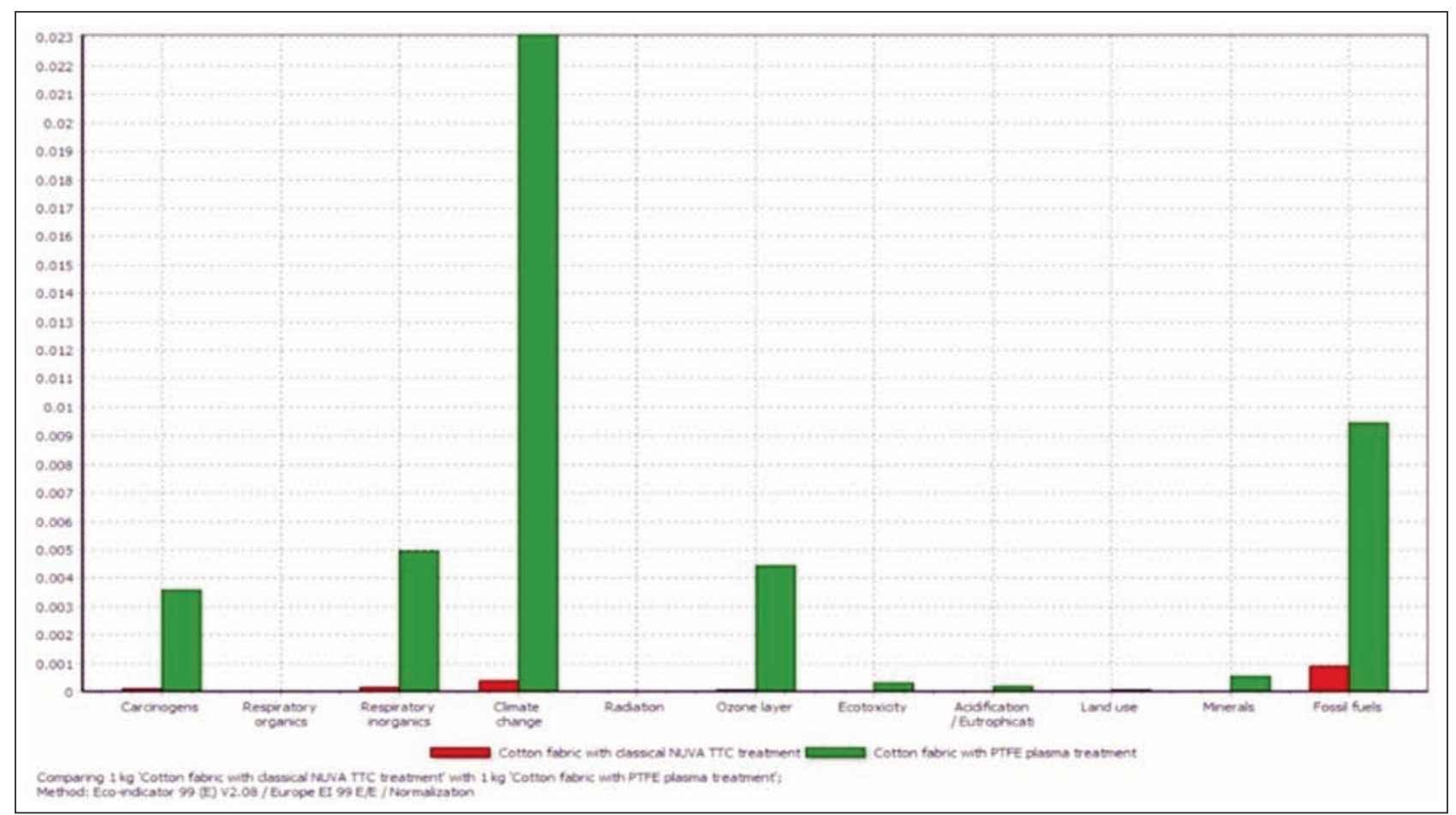

Fig. 3. The histogram of the LCA comparative assessment for hydrophobic cotton fabric obtained by foulard with NUVA TTC and by RF plasma (Teflon), using the normalization method

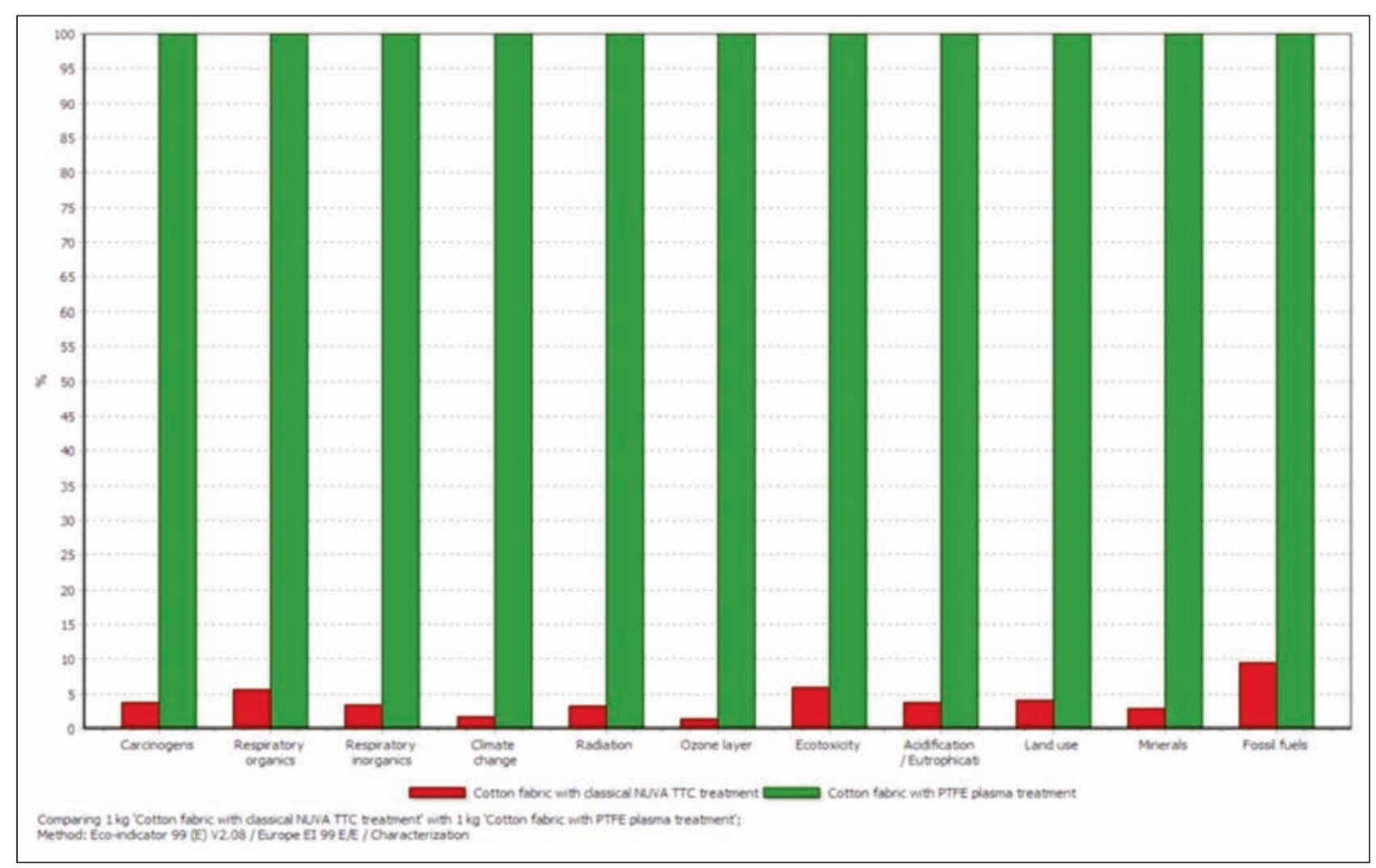

Fig. 4. The histogram of the LCA comparative assessment for hydrophobic cotton fabric obtained by foulard with NUVA TTC and by RF plasma (Teflon), using the characterization method

is evident that RF plasma technology based on fluorine compounds has a significant impact in comparison with standard treatment based on NUVA TTC. The advanced RF plasma treatments have a considerable influence on climate change due to the emissions with the greenhouse effect. Also, plasma tech- nology has a medium impact on fossil fuel consumption, on the ozone layer, by inorganics chemicals harmful for respiration and carcinogenic effect.

In figure 5 is presented comparative life cycle assessment based on weighting diagram and can be observed that RF plasma technology has a significant 


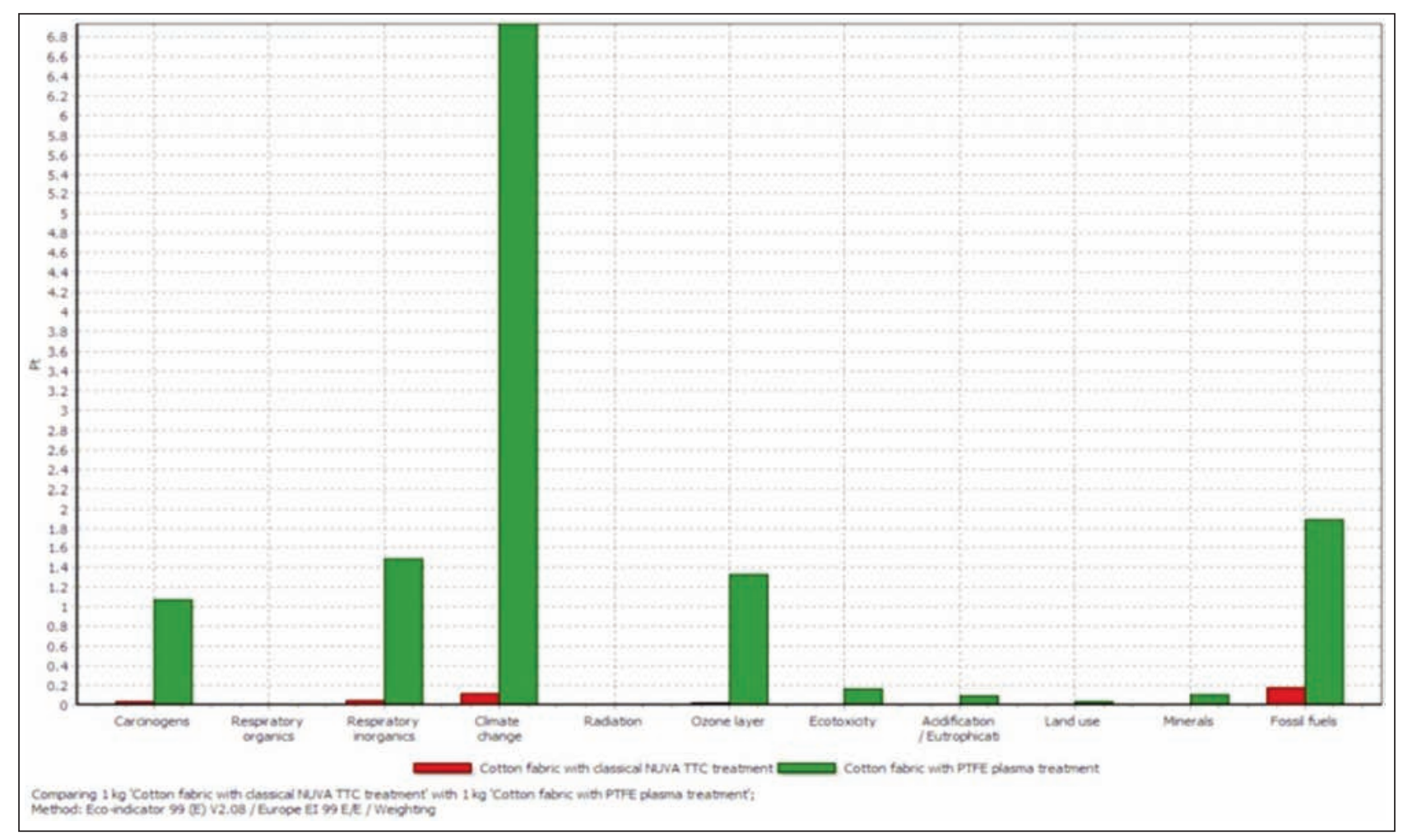

Fig. 5. The histogram of the LCA comparative assessment for hydrophobic cotton fabric obtained by foulard with NUVA TTC and by RF plasma (Teflon), using the weighting method

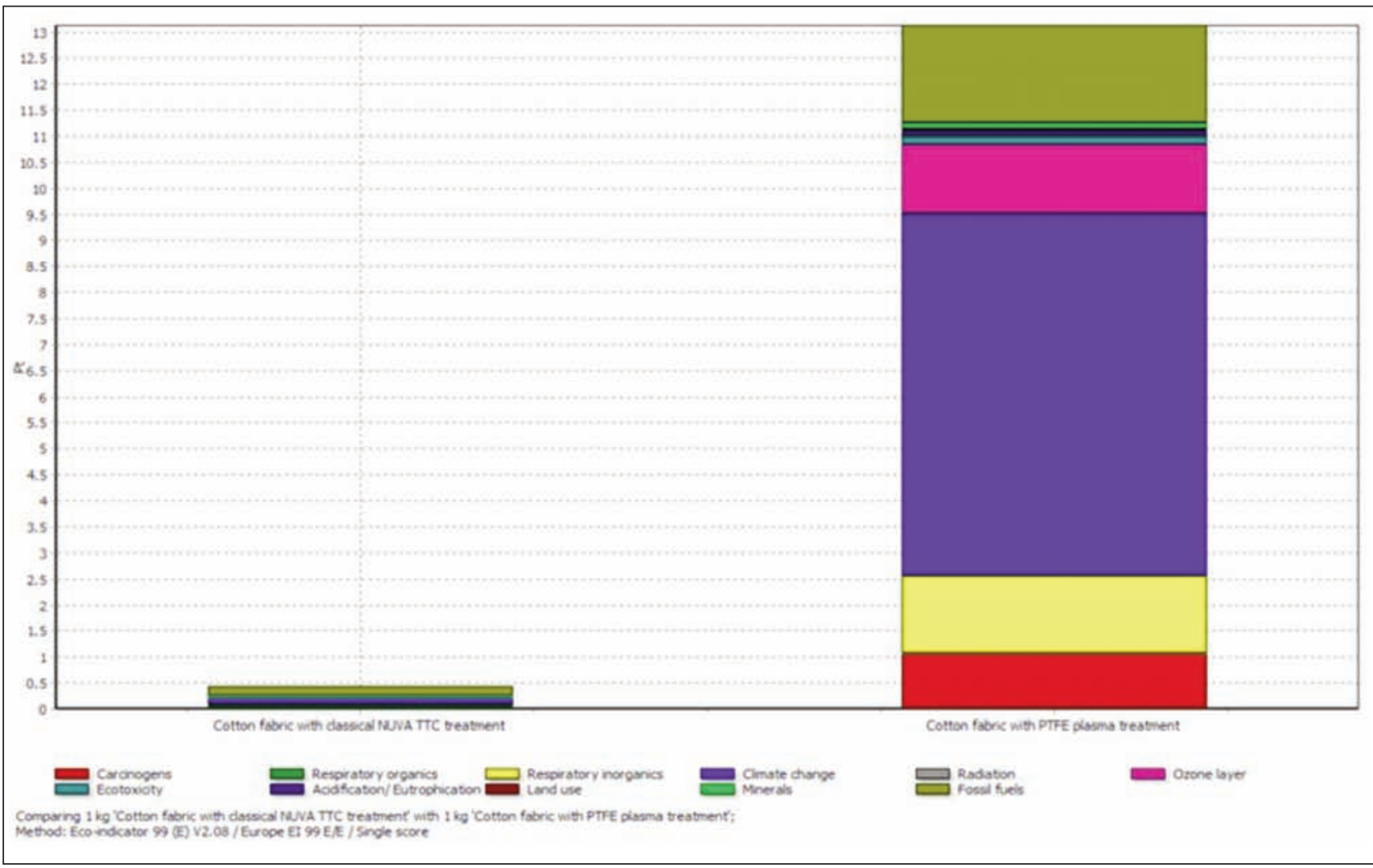

Fig. 6. The histogram of the LCA comparative assessment for hydrophobic cotton fabric obtained by foulard with NUVA TTC and by RF plasma (Teflon), using the Single Score method

impact on climate changes and small impact by inorganic chemical harmful by respiration, by reducing the ozone layer and by consumption of fossil fuels necessary for generating the electrical energy.

\section{CONCLUSIONS}

The investigation of the process and the diagram for environmental impact on different categories (EcoIndicator Method 99) [17-18] were prepared by 
weighting method, characterization, damage assessment, weighting, and normalization method. From all diagrams used in evaluation, we observed a significant impact of the classic hydrophobization (NUVA TTC) on fossil fuels, ecotoxicity by number of effects as acute and chronic toxicity on different species in water, harmful organic chemicals by respiration, chemicals with carcinogenic effect, ocean acidification by $\mathrm{CO}_{2}$ emissions into the atmosphere and harmful inorganic chemicals by respiration. Besides, RF plasma Teflon treatments have a significant impact on climate change, on the ozone layer, by inorganics chemicals harmful for respiration and carcinogenic effect. However, unlike traditional hydrophobization treatment, RF plasma technology low pressure used to obtain hydrophobic textile does not generate organics vapors, heat, and wastewater. The economy of the chemicals (fluorine compounds) gives the sustainability of the hydrophobization by RF plasma because the surface cleaning and hydrophobization are simultaneous. The typical hydrophobization process based on the foulard method generates toxical vapor, heat, and wastewater, while RF plasma does not generate wastewater generate some harmful emission discharged in the atmosphere. In comparison with the traditional process, the technology RF plasma is more expensive as device and maintenance, and request high qualified engineers.

\section{ACKNOWLEDGMENTS}

The research presented in this paper was prepared in the INCDTP laboratories. Funds support this work from ANCSI, National Project "The assessment of the life cycle of the hydrophobic textile materials", Contract PN 16340407.

\section{BIBLIOGRAPHY}

[1] Surdu, L., Radulescu, I.R. and Barbu, I. Life cycle assessment for medical textiles treated with plasma, In: Industria Textila, 2015, 66(6), pp. 360-364.

[2] Rauscher, H., Perucca, M. and Buyle, G. eds. Plasma technology for hyperfunctional surfaces: food, biomedical and textile applications, John Wiley \& Sons, 2010.

[3] Surdu, L., Surdu, I., and Radulescu, I.R. Research for accomplishing multifunctional textiles with plasma technology, In: Industria Textila, 2016, 67(5), p. 314.

[4] Nieminen, E., Linke, M., Tobler, M. and Vander Beke, B. EU COST Action 628: life cycle assessment (LCA) of textile products, eco-efficiency and definition of best available technology (BAT) of textile processing, In: Journal of Cleaner Production, 2007, 15(13-14), pp. 1259-1270.

[5] Aileni, R.M., Surdu, L., and Oksuz, L., May. Life cycle and environment impact for textile materials functionalized by using plasma technology, In: 2015 IEEE International Conference on Plasma Sciences (ICOPS), 2015, pp. 1-1, IEEE.

[6] Kiekens, P., Van der Burght, E., Kny, E., Uyar, T. and Milašius, R. Functional textiles - from research and development to innovations and industrial uptake, In: Autex Research Journal, 2014, 14(4), pp. 219-225.

[7] Bonaldi, R.R. Functional finishes for high-performance apparel, In: High-Performance Apparel, 2018, pp. 129-156, Woodhead Publishing.

[8] Miseljic, M. and Olsen, S.I. Life-cycle assessment of engineered nanomaterial: a literature review of assessment status, In: Journal of nanoparticle research, 2014, 16(6), p. 2427

[9] Curran M. A. Life Cycle Assessment Handbook, Wiley Publishing, USA, 2012.

[10] https://www.pre-sustainability.com/weighting-applying-a-value-judgement-to-lca-results.

[11] https://www.lokad.com/product-life-cycle-(inventory-planning).

[12] Sanfwon, Suh, Gjalt, Huppes, Methods for Life Cycle Inventory of a product, In: Journal of Cleaner Production, Vol. 13, Issue 7, pp. 687-697, 2005.

[13] Werner F., Ambiguities in decision-oriented life cycle inventories, Springer, 2005.

[14] Steward, M. and Weidema, B. A consistent framework for assessing the impacts of resource use. A focus on resource functionality, In: Int. J. Life Cycle Assess, 10 (4), pp. 240-247, 2004.

[15] Suh, S. Input-output and hybrid life cycle assessment, Int. J. Life Cycle Assess, 8 (5), p. 257, 2003.

[16] Herrera, I., Kulay, L., Jiménez, L. and Schuhmacher, M. Environmental Damage Assessment Applied to Process Analysis. A Decision Support Alternative, In: $1^{\text {st }}$ International Congress on Environmental Modelling and Software - Lugano, Switzerland, 2002.

[17] http://www.ecoinvent.org/

[18] Aileni, R. M., Dinca, L., Surdu, L. Textile surface hydrophobization by using plasma nanotechnology, In: Annals of the Academy of Romanian Scientists, Series on Science and Technology of Information, vol. 7, issue 2, pp. 43-48, 2014.

\section{Authors:}

RALUCA MARIA AILENI, LAURA CHIRIAC, ADRIANA SUBTIRICA, SILVIA ALBICI, LAURENTIU CRISTIAN DINCA

National Research \& Development Institute for Textiles and Leather, Lucretiu Patrascanu no.16, 030508 Bucharest, Romania

\section{Corresponding authors:}

RALUCA MARIA AILENI

e-mail: raluca.aileni@certex.ro 